\title{
EMERGENCY BRACHIARIA DECUMBENS A FUNCTION OF DEPTH OF SEEDS IN SOIL PROFILE
}

\author{
SILVA, Adilson Ferreira ${ }^{1}$ \\ PITELLI, Robinson Antonio ${ }^{2}$ \\ CRUZ, Claudinei ${ }^{3}$ \\ GARLICH, Nathalia ${ }^{1}$ \\ FLORÊNCIO, Taíse ${ }^{4}$
}

YAMAUCHI, Alfredo Kohiti Feres ${ }^{1}$

SUMMARY: The grass $B$. decumbens is the most cultivated pasture establishment in Brazil pastures and on areas used for other crops is amongst the more undesired weeds, due to hard control and rusticity. Therefore, the aim of this study was to determine the effects of sowing depths on $B$. decumbens emergence. The tests were performed on green house using the following sowing depths $(0.0,0.5,1.0,1.5,2.0,2.5,3.0,4.0,5.0,6.0,7.0,8.0,9.0$ e 10.0 $\mathrm{cm}$ ). From $7.0 \mathrm{~cm}$ deep occurred significant emergence speed index (SEI) and seedlings emergence percentage (\%ESI) reduction. In assessing the ability of germination of $B$. decumbens occurred suppression effect of germination in greater depth evaluated, while the other depths were tested emergency plan, with lower occurrence between 5 and $7 \mathrm{~cm}$ and topsoil. Layers between 0.5 and $2.5 \mathrm{~cm}$ larger plants des emergency occurred.

Keywords: Soil Seed Ban. Vigor. Weed.

\section{EMERGÊNCIA DE BRACHIARIA DECUMBENS EM FUNÇÃO DA PROFUNDIDADE DE SEMENTES NO PERFIL DO SOLO}

RESUMO: A gramínea B. decumbens é a mais cultivada em formação de pastagens no Brasil, em áreas onde são utilizadas para outros cultivos torna-se uma das plantas daninhas mais indesejadas, devido o seu difícil controle e rusticidade. Assim, o objetivo deste estudo foi determinar a emergência das plântulas de $B$. decumbens em profundidades de semeadura. Os ensaios foram realizados em casa de vegetação com as seguintes profundidades de semeadura $(0,0 ; 0,5 ; 1,0 ; 1,5 ; 2,0 ; 2,5 ; 3,0 ; 4,0 ; 5,0 ; 6,0 ; 7,0 ; 8,0 ; 9,0$ e $10,0 \mathrm{~cm})$. A partir de 7,0 cm de profundidade ocorreu redução significativa no índice de velocidade de emergência (IVE) e na porcentagem de emergência das plântulas (\%ESI) de $B$. decumbens. Na avaliação da habilidade de germinação da $B$. decumbens ocorreu efeito de supressão da germinação na maior profundidade avaliada, enquanto que, as demais profundidades testadas ocorreram emergência da planta, com menor ocorrencia entre 5 e $7 \mathrm{~cm}$ e na camada superficial do solo. Nas camadas entre 0,5 e 2,5 cm ocorreu maior emergência des plantas.

Palavras - chave: Banco de sementes em solo. Vigor. Planta daninha.

\footnotetext{
1 Pós graduação em Agronomia (Produção Vegetal) da Faculdade de Ciências Agrárias e Veterinárias da Unesp, Campus de Jaboticabal.

${ }^{2}$ Prof. Dr. Titular-Voluntário do Departamento de Fitossanidade da Faculdade de Ciências Agrárias e Veterinárias da Unesp, Campus de Jaboticabal.

${ }^{3}$ Núcleo de Estudos e Pesquisas Ambientais em Matologia da Unesp, Campus de Jaboticabal e Prof. Dr. do Centro Universitário da Fundação Educacional de Barretos. E-mail: claudineicruz@gmail.com

${ }^{4}$ Núcleo de Estudos e Pesquisas Ambientais em Matologia da Unesp, Campus de Jaboticabal.
} 


\section{INTRODUÇÃO}

Signal grass [Brachiaria decumbens $\mathrm{cv}$. Brasilisk (Stapt)] is an erect tussock grass, from Africa and belongs to Poaceae family. Is amongst the main forages on Brazilian livestock, but on the Midwest and Southeast regions is the most cultivated grass for pastures establishment due to high leaf biomass production with good quality, high resistance to heavy grazing and trampling (MOREIRA; BRAGANÇA, 2010), however this species may become one of the most undesired plants, due to aggressiveness, rusticity and hard control, causing negative interaction as native species extinction (VELMAN; PUTZ, 2011).

Considering this species importance, basic studies on its biology are necessary, however there are few studies in Brazil which clarify the involved mechanisms on weed emergence, as maximum depth which the seeds can emerge (LABONIA et al., 2009). Thereby, the soil seed bank is considered as a seed and vegetative propagules reservoir which constitutes the plants life cycle origin (SOUZA et al., 2009), and also contains many information about environmental conditions and previous cropping practices, which makes it an important factor for evaluation of weeds infestation potential on the present and future (CARNONA; BÔAS, 2001).

The vertical distribution of weeds seeds displays strict correlation to soil preparation. Mostly of positive photoblastic species as Conyza sp. (VIDAL et al., 2007), Erythrina velutina (CARDOSO et al., 2008) and Ipomoea sp. (LABONIA et al., 2009) demand a certain amount of light to start the germination process (RADOSEVICH et al., 2007). Whether any of these seeds is located on higher depths, their germination is compromised, differently from negative photoblastic species which doesn't need light stimulus, as Sida cordifolia (KLEIN; FELIPPE, 1991), Euphorbia hederifolia and Brachiaria plantaginea (SALVADOR, 2007) and Commelina benghalensis (DIAS et al., 2009).

Amongst the factors which determinate the passage of phenological stages from seeds to seedlings, the diaspore depth on soil profile is one of the most important and, undoubtedly, its evaluation is essential to develop population growth models and, with practical ends, to evaluate mechanic methods and chemical methods, isolated or associated, on weed control (CANOSSA et al., 2007; SOUZA et al., 2009).

Studies about diaspores population dynamics (RADOSEVICH et al., 2007) corroborate management strategies and help the understanding of seed banks formation dynamics in agricultural soils. Thus, the aim of this study was to determine the ability of emergency seed of $B$. decumbens at various depths in the soil profile. 


\section{MATERIAL AND METHODS}

The two experiments were conducted in the green house used arable layer of a red dystrophic latossol (380 g. $\mathrm{kg}^{-1}$ granulometry, with $50 \mathrm{~g} . \mathrm{kg}^{-1}$ of clay and silt and $570 \mathrm{~g} \cdot \mathrm{kg}^{-1}$ of sand). It was dry on shade with $25-30{ }^{\circ} \mathrm{C}$, followed by sieving on $5.0 \mathrm{~mm}$ mesh before being transferred to plastic boxes (EMBRAPa, 2006), with $2.5 \mathrm{~L}$, black colored to avoid light to interfere on results. The moisture was kept at $40 \%$ of soil field capacity, determined by the gravimetric method (RICHARDS, 1965).

The experiments were conducted for 21 days, according Souza-Filho et al. (2001), recommended that monitoring of plant emergence of grasses for 15 days after sowing (DAS), in randomized blocks design (RBD) with 14 treatments and four repetitions. The sowing depths were $0.0,0.5,1.0,1.5,2.0,2.5,3.0,4.0,5.0,6.0,7.0,8.0,9.0$ and $10.0 \mathrm{~cm}$. The depth of $10 \mathrm{~cm}$ was used as a depth limit because it is more common to the formation of seed banks weeds. Each box was considered an experimental unit and 50 seeds were sowed in each box, width $15 \mathrm{~cm}$ and height of $10.5 \mathrm{~cm}$.

B. decumbens emergence was evaluated each 48 hour and the emergence speed index (SEI) and the emergence percentage (ESI\%) were calculated based on the counting, according to Maguire (1962). For ESI\% calculation the data was transform by arc sen $\sqrt{x}+0.5$. The data was submitted to variance analysis (ANOVA) and the means were compared by Tukey test at 5\% level.

\section{RESULTS AND DISCUSSION}

At the first experiment, from the third DAS has occurred emergence at $0.0 ; 0.5 ; 1.0 ; 1.5$; $2.0 ; 2.5 ; 3.0 ; 4.0 ; 5.0 ; 6.0$ e $7.0 \mathrm{~cm}$ depths (Figure $1 \mathrm{~A}$ ). At $8.0 \mathrm{~cm}$ depth emergence has occurred from the seventh DAS and at $10.0 \mathrm{~cm}$ has occurred no seedlings emergence (Figure 1C). 
Figure 1 - B. decumbens seedlings emergence at sowing depths.
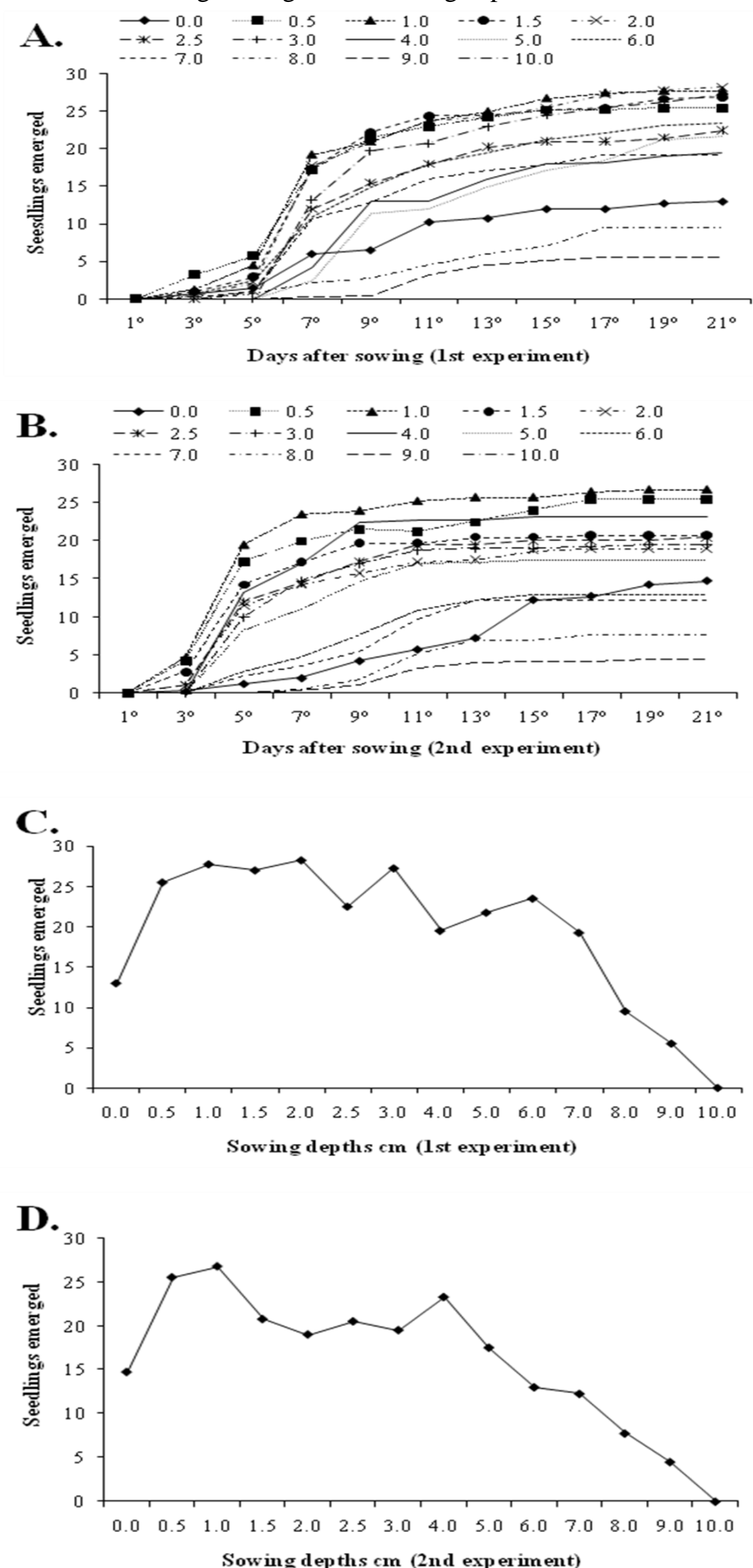
On the second trial, from the third DAS has occurred emergence at $0.0,0.5,1.0,1.5,2.0$ and $2.5 \mathrm{~cm}$ depths (Figure 1B). From the fifth DAS emergence occurred at 3.0, 4.0, 5.0, 6.0 and $7.0 \mathrm{~cm}$ depths. At 8.0 and 9.0 depths emergence occurred from the seventh DAS and at $10.0 \mathrm{~cm}$ has occurred no emergence of seedlings (Figure 1D).

The higher $B$. decumbens seedlings emergence percentage has occurred at 1.0 and $2.0 \mathrm{~cm}$ depths. These results were similar as those observed for Oenocarpus minor (SILVA E SILVA et al., 2006), Moringa oleifera (SOUZA et al., 2007), Erythrina velutina (CARDOSO et al., 2008) and Bidens pilosa (SOUZA et al., 2009).

The significant percentage reduction on this study occurred from $7.0 \mathrm{~cm}$ depth, with differ from Panicum dichotomiflorum, whereupon emergence was unfeasible at depths under $5.0 \mathrm{~cm}$ (FAUSEY; RENNER, 1997). Brachiaria subquadripara emergence was unfeasible at depths under $7.0 \mathrm{~cm}$ (TEUTON et al., 2004), Alternanthera tenella emergence was significantly reduced from $4.0 \mathrm{~cm}$ depth (CANOSSA et al., 2007) and for Ipomoea hederifolia the emergence was unfeasible from $2.0 \mathrm{~cm}$ depth (LABONIA et al., 2009).

The difference at cited emergence depth may has occurred due to seeds energetic reserve, since the bigger the seed (energetic reserve amount), the bigger is the chance of seedlings emergence from lower depths and they can survive longer on unfavorable environmental conditions (OLIVEIRA et al., 2005; GOMES JÚNIOR; CHRISTOFFOLETI, 2008). Araldi et al. (2013), evaluated accumulated emergence at sowing depths and observed resemblances between three seed classification sizes (small, medium and big).

On this study, emergence speed index (SEI) on both experiments was higher at 1.0 and $2.0 \mathrm{~cm}$ depth (Table 1), which corroborate with evaluation for Bidens pilosa $(1.0 \mathrm{~cm})$ (MUNIZ FILHO et al., 2004; Souza et al., 2009) and Alternanthera tenella $(1.0 \mathrm{~cm})$ (CANOSSA et al., 2007).

Table 1 - Emergence Speed Index (SEI) and emergence percentage (\%ESI) of $B$. decumbens seedlings. For $\% \mathrm{E}$, data was transformed in $\operatorname{arc} \operatorname{sen} \sqrt{\mathrm{x}}+0.5$.

(Continua)

\begin{tabular}{ccccc}
\hline \multirow{2}{*}{$\begin{array}{c}\text { Depths } \\
(\mathrm{cm})\end{array}$} & \multicolumn{2}{c}{ SEI } & \multicolumn{2}{c}{ Emergence percentage } \\
\cline { 2 - 5 } & $\begin{array}{c}1 \mathrm{st} \\
\text { experiment }\end{array}$ & $\begin{array}{c}\text { 2nd } \\
\text { experiment }\end{array}$ & $\begin{array}{c}1 \mathrm{st} \\
\text { experiment }\end{array}$ & $\begin{array}{c}\text { 2nd } \\
\text { experiment }\end{array}$ \\
\hline 0.0 & $6.69 \mathrm{def}$ & $4.38 \mathrm{ef}$ & $26.00 \mathrm{bc}$ & $29.50 \mathrm{bcde}$ \\
0.5 & $16.77 \mathrm{a}$ & $17.83 \mathrm{ab}$ & $51.00 \mathrm{a}$ & $51.00 \mathrm{ab}$ \\
1.0 & $16.67 \mathrm{a}$ & $20.03 \mathrm{a}$ & $55.53 \mathrm{a}$ & $53.50 \mathrm{a}$ \\
1.5 & $15.90 \mathrm{ab}$ & $15.10 \mathrm{abc}$ & $54.00 \mathrm{a}$ & $41.50 \mathrm{abc}$ \\
2.0 & $15.62 \mathrm{ab}$ & $12.36 \mathrm{bcd}$ & $56.50 \mathrm{a}$ & $38.00 \mathrm{abc}$ \\
2.5 & $11.67 \mathrm{abcd}$ & $13.22 \mathrm{bc}$ & $45.00 \mathrm{a}$ & $41.00 \mathrm{abc}$ \\
3.0 & $13.56 \mathrm{abc}$ & $12.25 \mathrm{bcd}$ & $54.50 \mathrm{a}$ & $39.00 \mathrm{abc}$ \\
4.0 & $8.67 \mathrm{cde}$ & $15.10 \mathrm{abc}$ & $39.00 \mathrm{ab}$ & $46.50 \mathrm{abc}$ \\
\hline
\end{tabular}


Table 1 - Emergence Speed Index (SEI) and emergence percentage (\%ESI) of B. decumbens seedlings. For $\% \mathrm{E}$, data was transformed in arc sen $\sqrt{\mathrm{x}}+0.5$.

(Conclusão)

\begin{tabular}{ccccc}
\hline 5.0 & $8.27 \mathrm{cdef}$ & $10.54 \mathrm{cde}$ & $43.50 \mathrm{ab}$ & $35.00 \mathrm{abcd}$ \\
6.0 & $12.19 \mathrm{abcd}$ & $6.10 \mathrm{def}$ & $47.00 \mathrm{a}$ & $26.00 \mathrm{cde}$ \\
7.0 & $10.26 \mathrm{bcd}$ & $5.34 \mathrm{ef}$ & $38.50 \mathrm{ab}$ & $24.50 \mathrm{cde}$ \\
8.0 & $3.63 \mathrm{efg}$ & $2.52 \mathrm{f}$ & $19.00 \mathrm{c}$ & $15.50 \mathrm{def}$ \\
9.0 & $1.94 \mathrm{fg}$ & $1.45 \mathrm{f}$ & $11.00 \mathrm{~cd}$ & $9.00 \mathrm{ef}$ \\
10.0 & $0.00 \mathrm{~g}$ & $0.06 \mathrm{f}$ & $0.00 \mathrm{~d}$ & $0.50 \mathrm{f}$ \\
\hline $\mathrm{DMS}$ & 6.35 & 6.42 & 18.54 & 22.23 \\
$\mathrm{CV}$ & 24.83 & 26.11 & 19.03 & 27.37 \\
$\mathrm{~F}$ & $19.36 * *$ & $25.28 * *$ & $23.84 * *$ & $23.66^{* *}$ \\
\hline
\end{tabular}

** Significant at $5 \%$ probability by $\mathrm{F}$ test

Means followed by the same letter in columns do not differ significantly by Tukey test at $5 \%$ probability.

However, this study differs from ESI obtained for Brachiaria brizantha cv. Piatã, which the highest SEI were obtained on depths between 0.0 and $3.0 \mathrm{~cm}$ (IKEDA et al., 2003). The low $\%$ ESI and SEI at lower depths may be attributed to survival strategy for weed seed bank formation.

B. decumbens emergence was affected by seeds location at the soil profile, therewith has occurred high intensity emergence reduction from $7.0 \mathrm{~cm}$ depth. Araldi et al. (2013) and Ikeda et al. (2013), also observed that sowing depth (B. decumbens) from 0.0 to $6.0 \mathrm{~cm}$ obtained the highest SEI.

This reproductive biology feature together with irregular germination guarantee the seed stock on soils and becomes a problem when develops at crop row from other crops, which may cause 30 to $80 \%$ reduction on maize production (PEREIRA; CAMPOS, 2001). On soybeans this may vary from 18 to $82 \%$ (FLECK, 1996) and on sugarcane the intense interference may cause up to $80 \%$ reduction on stalk production (KUVA et al., 2001).

One of the main $B$. decumbens interference justification is the agricultural use in remnant pastures area (BIANCO et al., 2000), such as the seed dispersion (anemochory) promotes fast invasion at parks and conservation units sited next to roads and prevent the species natural regenerative process, besides expand to neighbor areas, which represents risk to native species (ESPINDOLA et al., 2005). On the other hand, management (conventional soil preparation) may help introducing seeds sited from more surfacing layers to more deep layers (lower than $7.0 \mathrm{~cm}$, as seen in this study), which this seeds emergence is impaired, and also may bring deeper seeds to surfacing layers where herbicides may act on the germination of this seeds.

\section{CONCLUSION}

In assessing the ability of germination of $B$. decumbens occurred suppression effect of 
germination in greater depth evaluated, while the other depths were tested emergency plan, with lower occurrence between 5 and $7 \mathrm{~cm}$ and topsoil. Layers between 0.5 and $2.5 \mathrm{~cm}$ larger plants des emergency occurred.

\section{REFERENCES}

ARALDI, R. et al. Variação do tamanho de sementes de plantas e sua influência nos padrões de emergência das plântulas. Planta Daninha, v.31, p.117-126, 2013.

BIANCO, S. et al. Estimativa da área foliar de plantas daninhas: Brachiaria decumbens Stapf. e Brachiaria brizantha (Hochst.) Stapf. Planta Daninha, v.18, n.1, 2000.

CARDOSO, E.A. et al. Emergência de plântulas de Erythrina velutina em diferentes posições e profundidades de semeadura. Ciência Rural, v.38, n.9, p.2618-2621, 2008.

CANOSSA, R.S. et al. Profundidade de semeadura afetando a emergência de plântulas de Alternanthera tenella. Planta Daninha, v.25, n.4, p.719-725, 2007.

CARNONA, R.; BÔAS, H.D.C.V. Dinâmica de sementes de Bidens pilosa no solo. Pesquisa Agropecuária Brasileira, v.36, n.3, p.457-463, 2001.

DIAS, A.C.R. et al. Germinação de sementes aéreas pequenas de trapoeraba (Commelina benghalensis). Planta Daninha, v.27, p.931-939, 2009.

EMBRAPA - EMPRESA BRASILEIRA DE PESQUISA AGROPECUÁRIA. Centro Nacional de Pesquisa Agropecuária de Solos. Sistema brasileiro de classificação de solo. Embrapa Solos, 2006, 306p.

ESPÍNDOLA, M.B. et al. Recuperação ambiental e contaminação biológica: aspectos ecológicos e legais. Biotemas, v.18, n.1, p.27-38, 2005.

FAUSEY, J.C.; RENNER, K.A. Germination, emergence, and growth of giant foxtail Setaria faberi and fall Panicum, Panicum dichotomiflorum. Weed Science, v.45, n.3, p.423-425, 1997.

FLECK, N.G. Interferência de papuã (Brachiaria plantaginea) com soja e ganho de produtividade obtido através do seu controle. Pesquisa Agropecuária Gaúcha, v.2, n.1, p.63-68, 1996.

GOMES JR, F.G.; CHRISTOFFOLETI, P.J. Biologia e manejo de plantas daninhas em áreas de plantio direto. Planta Daninha, v.26, n.4, p.789-798, 2008.

IKEDA, F.S. et al. Emergência e crescimento inicial de cultivares de Urochloa em diferentes profundidades de semeadura. Planta Daninha, v.31, n.1, p.71-78, 2013.

KLEIN, A.; FELIPPE, G.M. Efeito da luz na germinação de sementes de ervas invasoras. Pesquisa Agropecuária Brasileira, v.26, n.7, p.955-966, 1991.

KUVA, M.A. et al. Período de interferência das plantas daninhas na cultura de cana-de-açúcar. II-Capim Braquiária (Brachiaria decumbens), Planta Daninha, v. 19, n. 3, p. 323-330, 2001. 
LABONIA, V.D.S. et al. Emergência de plantas da família convolvulaceae influenciada pela profundidade da semente no solo e cobertura com palha de cana-de-açúcar. Planta Daninha, v.27, p.921-929, 2009, Número Especial.

MAGUIRE, J.D. Speed of germination aid selection and evaluation for seedling emergence and vigor. Crop Science, v.2, n.2, p.176-177, 1962.

MOREIRA, H.J.C.; BRAGANÇA, H.B.N. Manual de identificação de plantas infestantes. Cultivo de verão, 2010. 642p.

MUNIZ FILHO, A. et al. Capacidade de emergência de picão preto em diferentes profundidades de semeadura. Revista de Biologia e Ciência da Terra, v.4, n.1, 2004.

OLLIVEIRA, I.V.M. et al. Influência do tamanho da semente na emergência das plântulas de longan (Dimocarpos longan). Revista Brasileira de Fruticultura, v.27, n.1, p.171-172, 2005.

PEREIRA, J.R.; CAMPOS, A.T. Controle da braquiária como invasora. Instrução técnica para o produtor de leite. Juiz de Fora: Embrapa Gado de Leite, 2001.

RADOSEVICH, S.R. et al. Ecology of weeds and invasive plants: relationship to agriculture and natural resource management. 3.ed. Hoboken: John Wiley \& Sons, 2007.

RICHARDS, L.A. Physical condition of water in soil. In: BLACK, C.A., ed. Methods of soil analysis. I. Physical and mineralogical properties including statistical of measuring and sampling. Madison, American Society of Agronomy, 1965. p.128-151. (Agronomy Series, 9).

SALVADOR, F.L. Germinação e emergência de plantas daninhas em função da luz e da palha de cana-de-açúcar (Saccharum spp.). 2007. 84 f. Dissertação (Mestrado em Fitotecnia) Escola Superior de Agricultura “Luiz de Queiroz”, Universidade de São Paulo, Piracicaba.

SILVA and SILVA, B.M. et al. Germinação de sementes e emergências de plântulas de Oenocarpus minor Mart. (ARECACEAE). Revista Brasileira de Fruticultura, v.28, n.2, p.289292, 2006.

SOUZA, A.H. et al. Profundidade e posição de semeadura na emergência e no desenvolvimento de plântulas de moringa. Caatinga, v.20, n.4, p. 56-60, 2007.

SOUZA, M.C. et al. Emergência de Bidens pilosa em diferentes profundidades de semeadura. Planta Daninha, v.27, n.1, p.29-34, 2009.

SOUZA FILHO, A.P.S. and ALVES, S.M. et al. Germinação de sementes de plantas daninhas de pastagens cultivadas: Mimosa pudica e Ipomoea asarifolia. Planta Daninha, v.19, n.1, p.23-31, 2001.

TEUTON, T.C. et al. Factors affecting seed germination of tropical signal grass (Urochloa subquadripara). Weed Science, v.52, n.3, p.376-381, 2004.

VIDAL, R.A. et al. Impacto da temperatura, irradiância e profundidade das sementes nas emergências e germinação de Conyza bonariensis e Conyza canadensis resistentes ao glyphosate. Planta Daninha, v.25, n.2, p.309-315, 2007.

VELDMAN, J.W. and PUTZ, F.E. Grass-dominated vegetation, not species-diverse natural savanna, replaces degraded tropical forests on the southern edge of the Amazon Basin. Biological Conservation. v.144, n.5, p.1419-1429, 2011. 